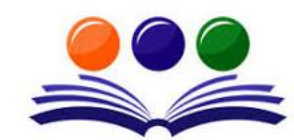

GRAND ACADEMIC PORTAL RESEARCH JOURNALS
A GLOBAL JOURNAL OF HUMANITIES

( ISSN - 2581-5857)

Impact Factor: SJIF - 5.171, IIFS - 5.125

\title{
PANCH DEV UPĀSANĀ (WORSHIP OF FIVE DEITIES)
}

\author{
Dr. N.R. Upadhyay, Goswami Pratibha H \\ Research Guide \\ Ph.D Research Scholar \\ Lakulish Yoga University \\ Higher Studies and Research Academy \\ Chharodi, Ahmedabad, Gujarat, India
}

\begin{abstract}
A person can achieve all the goals of one's worldly life as well one's spiritual life only when he is in good health. Scriptures also say that "sharira khalu mädhay dharma sādhanam" means the body is the real instrument for the spiritual path, so if it is not healthy we cannot enjoy either the material life, or the spiritual path. To be healthy we should maintain balance of the Panch Mahäbhuta (five elements) in our body and universe. Panch Dev Upāsanā is a means to help us maintain the balance of these Panch Mahäbhut in our body and in the universe. We can also achieve our final goal of liberation through the Upāsanā of Panch Dev which is advised and guided by our sages and scriptures.
\end{abstract}

\section{INTRODUCTION}

The ultimate, highest Truth, in the Hindu philosophy or Sanatana Dharma is Brahman. Brahman is the shapeless, formless, beginning-less, endless absolute, highest aspect of the Lord, and therefore is not an object that can be imagined or thought about. It is very hard to understand Brahman without a form, or a shape or some image. Humans can accept that which one can think about with his mind, feel with the heart and perform with actions.

For those who cannot understand the formless, Sanatana Dharma gives us a solution in the form of Panch Dev Upāsanā. Upāsanam panchavidham brahmopāsanamev tat means Panch Dev Upāsanā is the worship of Brahman. Panch Dev is the visible form of Brahman.

The main idea is that Panch Dev are not five different Lords, but they are different aspects of one and same absolute highest aspect of God - Brahman. Panch Dev is thus the one God worshipped in five different forms. Some sages believed that only Gyān is the way to achieve God, but it is not suited for all, so Shankaracharya has prescribed Karma (Action) in the form of poojā or Upāsanā to be done every day.

\section{THE DEFINITION OF PANCH DEV}

'Panch' means five, 'Dev' means Deity and one of the meanings of 'Upāsanā' is worship. Hence, to worship the prescribed five deities is Panch Dev Upāsanā. Panch Dev are also known as 'Panchāyatan'. Synonym for God in Sanskrit is 'Devatā' derived from Sanskrit root 'div', which means 'to make effulgent'.

\section{THE PRINCIPLE OF PANCH DEV UPĀSANĀ}

Panch Dev Upāsanā is performed as per the details given by our scriptures; this is not a matter of blind faith, but is backed by spiritual science. The whole created universe is based on Panch Mahābhut (five elements: ether, air, fire, water and earth) and our gross body is also composed of the Panch Mahābhut. Panch Dev are the presiding deities of these Mahābhutas, and hence Pach Dev Upāsanā is not related to any special religious worship. It is the Universal worship to get blessings from the Lord, which can be done by any and all human beings for good health and mental peace. Panch Dev are the representatives or manifestations of Brahman, and so they are all equal as well. Sagun Brahman (the Universal Lord with form) takes on five forms as Panch Dev and the Panch Mahābhut are created from the Maya of Brahman. The entire creation of visible things or beings can be visualized as it is made of the five elements, Panch Mahābhut.

\section{DEFINITION OF UPĀSANĀ}

The word Upāsanā consists of two other words: 'Upa' and 'Āsana'. 'Upa' means near and Āsana means to sit or to stay. 


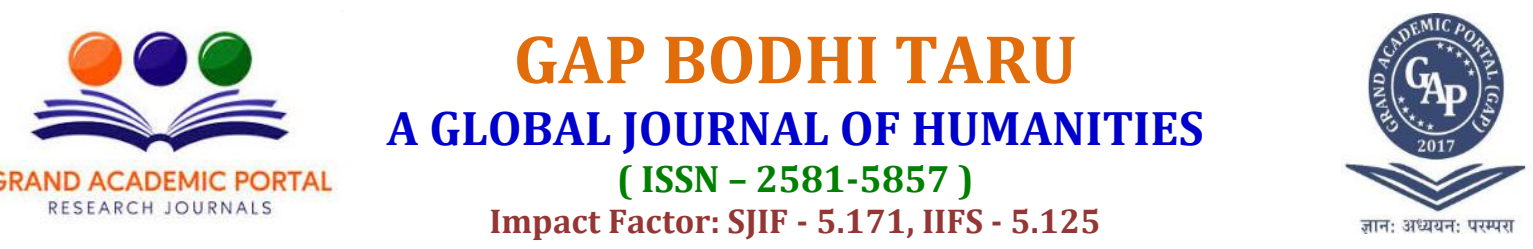

"Upāsanā means 'worship, to take seat beside God, to attain God, honoring the Lord, to perform the act of glorifying the Lord, performing Yogasādhanā, Meditation

Upāsanā should be performed only while sitting because in any other position the mind cannot be focused. Vyasaji has mentioned in the Brahmasutra "Āsinah sambhavāt" means sit down while worship, so Upāsanā can be performed with concentration.

Upagmyam àsanam iti Upāsañ̄ To take seat near the Lord is Upāsanā. It means one should feel that God is always with us, God is everywhere; keep the Lord in mind at all times. Devotees can feel that God is within me and I am in the God. He feels that I am Brahman, this is the real Upāsanā.

The complete meaning of Upāsanā is to always stay or sit near the Lord, to not feel separate from the Lord, to merge yourself within God. Upāsanā can be done for the procurement of material things also, but scriptures say that ideally it must be done with the sole aim of attaining to the truth, achieving liberation. Yo devm uttarāvantam upāsate sanātanam If the person worships (Upāsanā) the Lord, he will achieve the great eternal truth. Upāsanā is the means to achieve the truth of Supreme Reality, which can take a human being to immortality.

\section{WHAT IS DEV AND HOW MANY DEITIES ARE THERE IN SANATANA DHARMA?}

The auspicious sound "AUM" (svara) was uttered before the creation of the universe. After the sound AUM, Brahman was created the three God-heads, or Triumvarate - Lord Brahma, Lord Vishnu and Mahesh (Shiva). Lord Brahma is the Generator, Lord Vishnu is the Operator and Lord Mahesh (Shiva) is the Destroyer of the universe.

According to Vedic religion the number of Gods mentioned in major scriptures is 1(Brahman), 3(Brahma, Vishu, Mahesh), 5(Panch Dev- Shiva, Devi, Ganesha, Vishnu, Surya), and 33(12 Adityas, 8 Vasus, 11 Rudras and 2 Aswini kumars $12+8+11+2=33$ ), According to the three Vedas, God is present in the all human beings, animals, in all the elements of nature and all of creation, and reversely too, everything remains situated in God. The belief in Indian religion that there are 33 crore ("koti") Gods, really has another meaning behind it. The actual meaning of 33 'koti' is 33 types of deities which are accepted by most of the scriptures.

\section{Aim of Upāsanā}

The main aim of Upāsanā is to achieve (Moksha) liberation. People also perform Upāsanā for the fulfillment of comforts, sense pleasures, wealth, and other desires.

\section{How to succeed in Upāsanā:-}

There are four ways to get success in Upāsanā.

1. Shraddhā (trust, faith)

2. Vyākulatā (determination towards goal)

3. Sankalpatyāga (leave personal desires)

4. Samatā (stability)

\section{Sarvānga Upāsanā:-}

Sarvānga Upāsanā has four limbs and three types:

Four limbs of Sarvānga Upāsanā

1. Archanā (worship of the form of the Lord with an idol)

2. Stuti (chanting of stotra or shlok)

3. Japa (chanting)

4. Dhyan (meditation)

\section{Three types of Sarvānga Upāsanā}

Vedic Upāsanā should be performed only by a Brahmin, Kshatriya or Vaishya who has taken Upanayan Samskār Vedic, Tantric and Pauranic are 3 types of Upāsanā

1. Vedic Upāsanā:-

(a) Satyavatī Upāsanā:- Yoga Upāsanā is Satyavatī Upāsanā. The emotion and intellect should be focused in the same place where the eyes gaze: "drashtibuddhayoh sāmānādhikaranyen paryāptā upāsanā stavatī"

(b) Angavatī Upāsanā:- Vaishvānar upāsanā and Prānopāsanā are Angvati Upāsanā. Vaishvānar upāsanā has six limbs: Dhyu (sky to Dhruvaloka all the heaven is known as Dhyu), Āditya, Vāyu, Ākāsha, Āpa and Prithvī.

(c) Anyavatī Upāsanā: where the eyes focus on an idol or a symbol but intellect believes that this (idol/symbol) in reality is Brahman.

(d) Nidānvatī Upāsanā: this is the Sādhanā of non-dual Brahman, the Yogi of high level are performing this Upāsanā. 


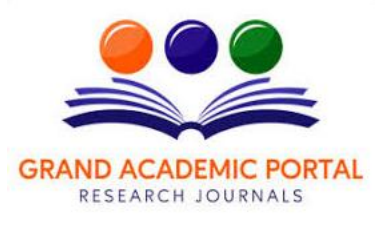

\section{GAP BODHI TARU A GLOBAL JOURNAL OF HUMANITIES ( ISSN - 2581-5857) \\ Impact Factor: SJIF - 5.171, IIFS - 5.125}

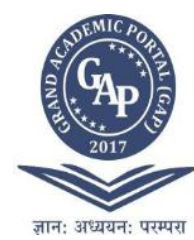

2. Tantric Upāsanā

The person who has not taken Upanayan Samskār is allowed to do this Tantric Upāsanā. Lord Shiva has given this Tantric Upāsanā for those who want libration. This is also Upāsanā of different Gods and Goddesses, but people misuse it and take it in a wrong way as tamasic Upāsanā.

3. Pauranic Upāsanā

The most common, popular way of worship or Upāsanā in our current times is the Pauranic Upāsanā. Gods and Goddesses are worshiped in this Upāsanā. This Upāsanā belongs to the worship of different incarnations of the Lord. The Puranas have mentioned so many types of Vrat, Upavās, poojā, stotra etc., which is all a part of Pauranic Upasana.

\section{Panch Dev Upāsanā}

Panch Dev are the five Deities and Upāsanā is the worshiping of Brahman. Panch Dev are the visible form of Brahman.

Ādityam gananātham cha devīm rudram cha keshavam! Panchadaivatamityuktam sarvakarmasu pujayet Surya, Ganesha, Devi, Shiva and Vishnu are the five deities known as Panchadevata or Panch Dev. They should be worshiped in all the rituals.

Evam yo bhajate vishnum rudram durgam ganādhipam! Bhāskaram cha dhiyā nityam sa kadāchinna sìdati

One who worships Vishnu, Rudra, Durga, Ganesh and Surya with faith will ever be effulgent in mind and intellect, and will never face sorrow.

Panch Dev Upāsanā is to worship Brahman the Supreme Soul. Hindu scriptures say that "Upāsanam panchavidham brahmopãsanamev tat, meaning that worshiping Panch Dev is the worship of Brahman (the Supreme Reality).

While Shankrāchārya himself believes in the non-dual Brahman, Supreme Reality, he has given what is known as "Shanmat". 'Shan' means six and 'Mat' means 'Path.' The six paths leading to the Lord, or the six ways of worshiping the Lord. One of these six paths is 'Advaita', non dualism or non-duality, which believes that there is no other truth than Brahman, the formless Lord. 'Nirguna' literally means 'without qualities', or 'without the three gunas of Prakriti - sattva, rajas, tamas'. One can worship this formless Lord, the Soul, Âtmān, the Supreme Reality, Brahman, and this is called Nirguna Upāsanā; and worship of the five deities with form is 'Sagun' or 'with form' upāsanā. 'Panch Dev Upāsanā' is saguna upāsanā. Shankaracharya propounded that while Nirguna Upāsanā also must be done, so too, should everyone worship the Panch Dev. There is no harm on the path of Brahman worship while worshiping the Panch dev at the same time. "Rupaistu tairapi bibhāsi yatastvamekah Means "Devotees worship the Lord according to their faith and prakriti (Nature), but God is only one who is presented in different forms"

The position of Panch Dev in Temple at home

Every Hindu must have a dedicated place of worship at home, where daily worship of the Lord must be performed. One's Ishta Dev (chosen/most loved form of the Lord) must be kept in the center and other four deities should be arranged around. The procedure with which the Panch Dev Upasana must be done, as per the scriptures, is as follows:

Ādityam gananātham cha devīm rudram cha keshavam: The worship starts with Lord Surya (Āditya), Ganesha, Devi (Durgā), Rudra (Shiva) and then Vishnu.

The Panch Dev position should be according to the Ishtadeva in the home.

Shaiva Panchāyatana:
Vishnu Surya
Shiva
Durgā Ganesh

Lord Vishnu should be kept in the Northeast (Ishān) direction. Lord Surya should be kept in the Southeast (Agneya) direction. Lord Shiva stays in the center of Panchāyatan poojā. Lord Ganesha should be kept in the Southwest (Nairutya) direction. Goddess Durgā should be kept in the Northwest (Vāyavya) direction.

Vishnu Panchāyatana:

Shiva Ganesha Vishnu

Durgā Surya

Lord Shiva should be kept in the Northeast (Ishān) direction. Lord Ganesha should be kept in the Southeast (Agneya) direction. Lord Vishnu stays in the center of Panchāyatan poojā. Lord Surya should be kept in the Southwest (Nairutya) direction. Goddess Durgā should be kept in the Northwest (Vāyavya) direction. 


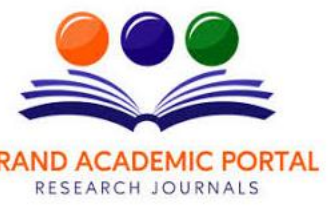

Surya Panchāyatana:

Shiva Ganesha Surya

Durgā Vishnu

Lord Shiva should be kept in the Northeast (Ishān) direction. Lord Ganesha should be kept in the Southeast (Agneya) direction. Lord Surya stays in the center of Panchāyatan poojā. Lord Vishnu should be kept in the Southwest (Nairutya) direction. Goddess Durgā should be kept in the Northwest (Vāyavya) direction.

Durgā Panchāyatana:

Vishnu Shiva

Durgā

Surya Ganesh

Lord Vishnu should be kept in the Northeast (Ishān) direction. Lord Shiva should be kept in the Southeast (Agneya) direction. Goddess Durgā stays in the center of Panchāyatan poojā. Lord Ganesha should be kept in the Southwest (Nairutya) direction. Lord Surya should be kept in the Northwest (Vāyavya) direction.

\section{Deities of Panch Mahābhut}

The idol in the Panch Dev Upāsanā is not made of any metal but they are natural stones found in various parts of India. They are known as 'Archa Vigrah' means 'Idol worship' of 'Ling' or symbol. Pach Dev are also worshiped as Murti (statue).

As stated earlier, Panch Dev are the deities of Panch Mahābhut/the five elements: earth, water, fire, air and ether. Ākāshasyādhipo vishnurgnecchaiva maheshwari | vāyoho suryah kshiterīsho jīvanasya ganadhipah According to this shloka, the deities of the various Pancha Mahābhutas, or the five elements are as follows:

1. Vyoma, Ākāsha (ether, sky): Vishnu

2. Tej, Agni (Fire): Maheshvari (Durga)

3. Maruta, Vāyu (Air): Surya

4. Kshiti, Prithvi (Earth): Shiva

5. Āpa, Jal (Water): Ganesha

These Panch Dev are believed to be manifestations of Brahman in the form of each Panch Mahabhuta (Five Elements).

\section{Lord Surya (Sun)}

Surya ätmā jagatastasthushccha means 'Sun is the soul of whole universe'. Lord Surya incarnated as the son of Aditi and Kashyapa, and was materialized from one of rays of the Sun known as 'Sidhuman'. Lord Surya is Aditi's son so known as Aditya. He is very brilliant and rides in a beautiful chariot drawn by seven white horses. $\mathrm{He}$ is the solar deity. He maintains the cycle of day and night on the earth. He works 24 hours; if it is night on the one side of earth, on the other side it is day. The meaning of Surya in Sanskrit is Sarati (gachchhati) äkāshe iti suryah means 'who appears to be constantly moving in the sky is Surya' He gives vital Prana and energy to the living creatures. He is known as the life of all creatures. Udhdhyantu khalu vā äityah sarvani bhutāni prānayati tasmādenam prāna ityāchakshte, meaning 'Surya is the one who gives energy and life to all the creatures of universe'. Ädityo ha vai prānah, means 'Surya can provide Prāna (vital energy) when he rises. Scriptures say that Surya is the protector of the living and non-living beings on the earth. He also provides them enough energy and power to survive.

\section{Lord Ganesha}

'Ganesh' consists of two words 'Gana' and 'Isha'. 'Gana' means a group, a class, a lot of or many deities. 'Isha' means 'leader'. Thus, “Ganesh" means "leader of a class of deities". The 12 Ādityas, 8 Vasus and 11 Rudras are also known as 'Ganas' so Lord Ganesh is the leader of all these deities. According to the Sage Patanjali, we have seven Chakras in our body, and every chakra has a ruling deity. Lord Ganesh is the presiding deity of the Base Chakra - Mulādhāra. All the Hindus irrespective of their religion worship the Lord Ganesh before starting any new work or project. Lord Ganesh is known as 'Pratham Pujya Dev' or the first deity to be invoked while doing any pooja/worship. He is worshiped at the beginning of any religious rituals too. Hindu scriptures say that Ādipujyam ganādhyaksham umāputram vināyakam! Mangalam paramam rupam shrīganesham namāmyaham

\section{Devi (Shakti) (Goddess)}

Devi means Goddess. She is also known as Shakti in the scriptures; 'Shakti' or 'Parāshakti' meaning nature, energy, power, strength, force, goddess, the highest form of life energy, primordial cosmic energy, substantive, divine energy. Every Hindu sect believes in Kuladevi - a Divine female deity worshipped by the clan. The family deity who is the mother goddess is known as Kuladevi. She protects, blesses and helps to remove all the obstacles of the devotee. 


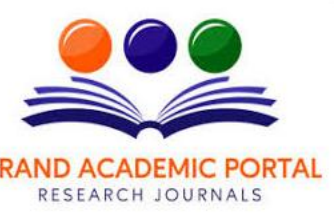

\section{GAP BODHI TARU A GLOBAL JOURNAL OF HUMANITIES}

( ISSN - 2581-5857)

Impact Factor: SJIF - 5.171, IIFS - 5.125

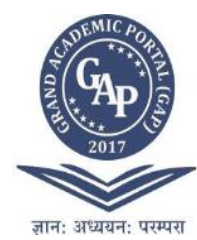

Prakriti is the female creative power of Brahman, and is separated from Brahman to create the universe with the help of the seed of Brahman. Scripture says: "tvamev sarvajanani mulaprakrutirīshvarī! Tvamevādhyā srustividhyau svechchhayā trigunātmikā means 'Devi is the universal mother, root Prakriti (Nature) and goddess. She has been there as Ādhyāshati while the universe was created. She possesses three qualities (sattva, rajas and tamas) with her own wish.'

\section{Lord Shiva}

Lord Shiva is 'Swayambhu', self-manifested or self existing. He is the one who, after the end of the world, removes all darkness and once again lets there be light, or makes everything effulgent. Lord Krishna, in the Bhagvad Gita says, "updrashtānumantā cha bhartā bhoktā maheshwarah! Paramātmeti chāpyukto dehesmin purushah parah Meaning yes in this there is another, a transcendental enjoyer, who is the Lord, the supreme proprietor, who exist as the overseer and permitter, and who is known as the Supremesoul Lord Maheswara (Shiva). Shiva Purana says that Shiva is Brahman. He is not bound with Prakriti (nature) or Purusha (soul). Tasya prakrutilinasya yah parah sa maheswarah! Tadhdina pravruttivāt prakruteh purushshya chaMeaning Prakriti and Purusha cannot bind Lord Shiva, he is free from all bondages of actions (karma). He is the destroyer; He destroys the universe according to his own wish. Vishrämasthänamev Shiva is the place of all living beings to have the final rest after the end of their life.

\section{Lord Vishnu}

"Vishnu", this word is derived from Sanskrit 'vishlru' means 'universal' or 'worldwide'. "Veveshti vyāpnoti iti vishnuh" means 'Lord Vishnu exists in all the species.' He is everywhere, worldwide and universal. He is the embodiment of sattva guna (quality of nature relating to purity, light). He sustains all the living beings in the universe. He has the quality of mercy and goodness which manifests itself as the preserving or sustaining power, self-existent and all-pervading spirit. Votaries of Vishnu associate him with the water element Kshirasāgara or the Ocean of milk, and we call him Nārāyana - one who moves in the water (naara aapah). He is depicted reclining comfortably in the ocean on the seat of Shesha - the primordial serpent having a thousand hoods (Sahasraphana), with his consort Lakshmi sitting beside him, and he wears a yellow garment pitambara, and ornaments like the Kaustaubha mani-gem. He is also depicted in a state of Yognidra - sustained sleep induced through yoga. The Narada Purana mentions three forms of Vishu: 'vishnostu trīni rupāni purushākhyānyato viduh! Ekam tu mahatah srashtru dvitīyam tvandasansthitam!! trutīyam sarvabhutastham tāni gnātvā vimuchyate Meaning, "Lord Vishnu, whom the gyani (knowledgeable one/learned) knows as Purush, has three forms. The first form of the Lord is the creator of Mahat Tattva. His second form is his seat in the whole creation as 'Antaryami', the universal subtle body, knower of all. And his third form seated in all consciousness, living beings as their individual consciousness.

\section{CONCLUSION}

The actual goal of each human soul is to become free from the cycle of life and death. Liberation is not an easy task to get. To achieve liberation, we must cross many hurdles in our human life. Upāsanā (worship) of God or Pranopāsanā is the path to achieve our highest goal of liberation. Upāsanā can be of two types: Saguna (with form) and Nirguna (formless). All other Upāsanā falls under these two categories. The Vedas and other scriptures explain clearly that Supreme God is 'Omni', 'all, including everything or everywhere'. He is Brahman, shapeless, formless, beginning-less, endless, beyond the qualities, beyond time and space itself. Brahman is eternal, and the one and only truth.

Brahman is not a limited object that can be cognized or known by the senses and the mind. Then how can it be possible to reach Braham which is unreachable. How can it be possible to see Brahman that is formless? How can one describe Brahman who cannot be described? Brahman has no boundary of time and space. At the start of creation, Brahman manifests itself in the form of Gods and Goddesses. Since Brahman has no form, it is impossible for a human to focus on something formless for mediation. Our scriptures say that the Panch Dev represents Brahman with name and form, so we can focus, meditate and worship easily.

Humans have their own choice, emotion and thought so he chooses that deity to worship which is most dear to him and suits his own personality and faith. Panch Dev Upāsanā is performed as per the details given by our scriptures. The whole universe is based on Panch Mahābhut (five elements ether, air, fire, water and earth) and our gross body is composed of the Panch Mahābhut. Human body is also made with Panch Mahābhuta (five physical elements), five Tanmātras (Subtle Elements - speech, touch, form, taste and smell), Gyānedriyas (five organs of senses) and Karmendriyas (five organs of actions). According to Sānkhya philosophy our human body is made from 24 elements, and in Yoga philosophy, 25 elements.

All of creation is made of these Panch Mahābhuta, so after death, the human body dissolves into these Panch Mahābhuta which balances the cycle of nature. These Panch Mahābhuta are connected to each other. Without any one of these Panch Mahābhutas, the universe would not exist and their imbalance in human body creates disease. It is our duty to maintain the balance of these Panch Mahābhut in our body and the universe, so worshiping of Panch Dev is worshiping the Panch Mahābhut and also it is worshiping Brahman itself. 


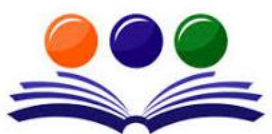

GRAND ACADEMIC PORTAL RESEARCH JOURNALS

\section{A GLOBAL JOURNAL OF HUMANITIES ( ISSN - 2581-5857) \\ Impact Factor: SJIF - 5.171, IIFS - 5.125}

Panch Dev are the deity of five elements which also exists in every human being. It means panch Dev Upāsanā is the universal worship and it is not limited to any specific religion or sect.

\section{REFERENCE}

[1] Shree Ganesha Anka ; Kalyana January 1974, Gitapress Gorakhapura

[2] Surya Anka; Kalyana - January 1979, Gitapress Gorakhapura

[3] Shree Vishnu Ank, Kalyana - January 1973, Gitapress Gorakhapura

[4] Shivopasana Ank, Kalyana - January 1993, Gitapress Gorakhapura

[5] Shakti Upasana Anka, Kalyana - January 1987, Gitapress Gorakhapura

[6] Upasana Anka, Kalyana - January 1968, Gitapress Gorakhapura

[7] Pujanatraya by Swamini Vidhyaprakashananda, Adhyatam Vidhyamandir, Ahamedabad

[8] Brahmavaivarta Purana, Prakruti khand - 2, Sastu Sahitya - 1970

[9] Shreemad Bhagvat Gita, Swami Prabhupad, The Bhaktivedanta Trust

[10] Shiva Mahapuran, Vāyaviya samhirta , Gitapress Gorakhapur

[11] Prashnopanishad - (Ishanadi nau Upanishad, Gita Press, Gorakhapur)

[12] Rigved Bhashya, Vanprastha Sadhak Ashram, Ayavan, Gujarat,

[13] Yajurved Bhasyam, Vanprastha Sadhak Ashram, Ayavan, Gujarat, 